\title{
Statement at UNHCR's 2003 Executive Committee
}

\author{
Hon. Omar Ramadhan Mapuri
}

\begin{abstract}
On September 29, 2003, at the $54^{\text {th }}$ session of UNHCR's Executive Committee, High Commissioner Ruud Lubbers convened a panel discussion entitled "Implemention of UNHCR 2004." The process dubbed "UNHCR 2004" followed closely on the heels of UNHCR's Global Consultations on International Protection and was intended to focus more closely on UNHCR's position within the United Nations system and its relationship with states and non-governmental partners.

One of the participants in this panel discussion was the Honourable Omar Ramadhan Mapuri, Minister for Home Affairs of the United Republic of Tanzania. Tanzania hosts more refugees than any other African country. More than half a million refugees, mostly from Burundi and the Democratic Republic of Congo, live in UNHCR camps in the west of the country. Minister Mapuri's statement, reproduced below with his permission, reflects many of the frustrations of refugee-hosting countries in the developing world.
\end{abstract}

\section{Résumé}

Le 29 septembre 2003, à la 54ession du Comité Exécutif du UNHCR, le Haut Commissaire Ruud Lubbers convoqua une table ronde du nom de "Implementation of UNHCR 2004 » ('Mise en ouvre de UNHCR 2004'). L'initiative appelée "UNHCR 2004 » suivit de près une autre initiative du UNHCR «Global Consultations on International Protection" ('Consultations globales sur la protection internationale'), et avait pour objectif d'examiner de plus près la place qu'occupe le UNHCR dans le système des Nations Unies et sa relation avec les états et ses partenaires non gouvernementaux.
Un des participants à cette table ronde fut l'honorable Omar Ramadhan Mapuri, le Ministre des Affaires intérieures de la République Unie de Tanzanie. Il faut savoir que la Tanzanie abrite plus de réfugiés que n’importe quel autre pays africain. Plus d'un demi million de réfugiés - principalement du Burundi et de la République Démocratique du Congo - habitent dans les camps $d u$ UNHCR situés dans l'ouest du pays. Les propos $d u$ ministre Mapuri, que nous reproduisons ici avec sa permission, reflètent beaucoup de frustrations que connaissent les pays du tiers monde abritant des réfugiés.

I

would like to thank the High Commissioner for extending the invitation to me to participate in this panel discussion on the theme of "Implementation of UNHCR 2004." I consider this initative as timely, particularly at this stage when there are many global challenges in almost every aspect of the refugee protection and assistance agenda.

Let me start my presentation with the following assumptions:

1. that this forum is aware of the huge price being paid by countries like Tanzania hosting large numbers of refugees in terms of retarded socio-economic development, environmental degradation, and even internal political backlash;

2. that this forum is aware of the general underfunding of refugee protection and assistance programs by the international community, thus leaving most of the burden to care for the refugees on the lean shoulders of poor refugee-hosting countries;

3. and that this forum is open to new ideas towards addressing pertinent refugee protection issues emanating from experiences of different stakeholders, particularly countries hosting large numbers of refugees. 
With those assumptions in mind, I now wish to comment on a few issues raised and some not raised in the High Commissioner's report to the Executive Committee.

First is the issue of resettlement. Resettlement should be seen not only as a protection-focused mechanism, but also as a durable solution based on the contribution that refugees can make to the economies of resettlement countries and as a burden-sharing mechanism. Unfortunately, what seems to be taking place is for the resettlement countries to pick those refugees that they see as assets, leaving behind those they consider liabilities. The ones left behind are usually the uneducated, the aged, the vulnerable, and the ailing, including HIV/AIDS victims. Since countries like mine that host large numbers of refugees are some of the world's poorest, it becomes a burden that those countries have to continue shouldering without much substantial assistance. A proper and justifiable mechanism needs to be worked out in the resettlement process that will ensure equitable burden sharing between UNHCR, the country of first asylum, and the resettlement country.

The second issue I would like to comment on is that of facilitating local integration and taking it as a yardstick for additional development assistance to refugees in a particular country. I would like to reiterate my country's position that local integration of large numbers of refugees may not always be a viable option. In Tanzania, for example, we have both settings where we consider it viable (in respect of the 3,000 Somali refugees) and where we do not consider it viable (in respect of the nearly 1,000,000 refugees from countries of the Great Lakes region). I have noted with relief the High Commissioner's recognition in his report that local integration may not be viable in some settings. In my view, we should refrain from making the local integration of refugees mandatory and a condition for the international community to discharge its burden-sharing responsibility in supporting countries of asylum.

Regarding returnees, I fully concur with the High Commissioner's stance, and there was a convergence of minds at the recent meeting in Dar es Salaam of East African and Great Lakes countries, regarding the need for the protection of and assistance to returnees, to ensure their successful reintegration and to kick-start economic activities that focus on their potential.

Allow me also to shed further light on Tanzania's current advocacy for the creation of "save havens" within the boundaries of a refugee-producing country, as a refugee protection option which could be considered where circumstances allow. Tanzania will always remain open for bona fide asylum seekers. But it is our considered opinion that within the period of one year, the international community should be able, subject to the realities on the ground, to set up "safe havens" to which the influx of refugees would be taken and where they would be looked after pending reintegration into their respective home areas when the conflict is brought to an end.

Although there were problems encountered when the arrangement was tried for the first time in Bosnia, the international community is capable of improving on it, if it has the political will. We in Tanzania feel that internal "safe havens" will prevent the spillover to other countries of the effects of the causes of the conflicts that produced the refugees in the first place. Second, "safe havens" will reduce existing contradictions between the treatment of internally displaced persons and refugees. Both groups of affected human beings should be entitled to the same range of human rights and protection regimes. A third case for "safe havens" is that they will generate more effective pressure on the international community and the parties to the conflict to work towards reconciliation and eventual restoration of peace. Fourthly, alleged "benefits"said to accrue to refugeehosting countries will benefit the refugees' own countries of origin.

Finally, but not least, "safe havens" will reduce undue tensions that have tended to crop up at times between refugee-generating and refugee-hosting countries.

I wish to conclude by fully supporting the High Commissioner's proposal to lift the time limitation on UNHCR's mandate. Experience has shown in no uncertain terms that the UNHCR is not only there to stay, but its role is actually increasing.

The Honourable Omar Ramadhan Mapuri is Minister for Home Affairs of the United Republic of Tanzania. 